\title{
Recent advances in understanding the mechanisms
}

\section{determining longevity [version 1; peer review: 3 approved]}

\author{
Robert Bayersdorf1,2, Björn Schumacher (iD)1,2 \\ ${ }^{1}$ Institute for Genome Stability in Aging and Disease, Medical Faculty, University of Cologne, Cologne, Germany \\ ${ }^{2}$ Cologne Excellence Cluster for Cellular Stress Responses in Ageing-Associated Diseases (CECAD), Center for Molecular Medicine \\ Cologne, University of Cologne, Cologne, Germany
}

V1 First published: 09 Aug 2019, 8(F1000 Faculty Rev):1403

https://doi.org/10.12688/f1000research.19610.1

Latest published: 09 Aug 2019, 8(F1000 Faculty Rev):1403

https://doi.org/10.12688/f1000research.19610.1

\section{Abstract}

The field of aging research has progressed significantly over the past decades. Exogenously and endogenously inflicted molecular damage ranging from genotoxic to organellar damage drives the aging process. Repair mechanisms and compensatory responses counteract the detrimental consequences of the various damage types. Here, we discuss recent progress in understanding cellular mechanisms and interconnections between signaling pathways that control longevity. We summarize cell-autonomous and non-cell-autonomous mechanisms that impact the cellular and organismal aging process

Keywords

Ageing, longevity, DNA repair, autophagy, senescence, C. elegans

\section{Open Peer Review}

Approval Status

1

2

3

version 1

09 Aug 2019

Faculty Reviews are review articles written by the prestigious Members of Faculty Opinions. The articles are commissioned and peer reviewed before publication to ensure that the final, published version is comprehensive and accessible. The reviewers who approved the final version are listed with their names and affiliations.

1. Evgeny Nudler, New York University School of Medicine, New York, USA

2. Jan Vijg, Albert Einstein College of Medicine, New York, USA

3. K Lenhard Rudolph, Leibniz Institute on Aging, Fritz Lipmann Institute (FLI), Jena, Germany

Any comments on the article can be found at the end of the article. 
Corresponding author: Björn Schumacher (bjoern.schumacher@uni-koeln.de)

Author roles: Bayersdorf R: Conceptualization, Writing - Original Draft Preparation; Schumacher B: Conceptualization, Writing Review \& Editing

Competing interests: No competing interests were disclosed.

Grant information: BS acknowledges funding from the Deutsche Forschungsgemeinschaft (SCHU 2494/3-1, SCHU 2494/7-1, CECAD, SFB 829, SFB 670, KFO 286, KFO 329, and GRK2407), the Deutsche Krebshilfe (70112899), and the European Cooperation in Science and Technology (COST) action (BM1408).

The funders had no role in study design, data collection and analysis, decision to publish, or preparation of the manuscript.

Copyright: $\odot 2019$ Bayersdorf R and Schumacher B. This is an open access article distributed under the terms of the Creative Commons Attribution License, which permits unrestricted use, distribution, and reproduction in any medium, provided the original work is properly cited.

How to cite this article: Bayersdorf $\mathrm{R}$ and Schumacher $\mathrm{B}$. Recent advances in understanding the mechanisms determining longevity [version 1; peer review: 3 approved] F1000Research 2019, 8(F1000 Faculty Rev):1403

https://doi.org/10.12688/f1000research.19610.1

First published: 09 Aug 2019, 8(F1000 Faculty Rev):1403 https://doi.org/10.12688/f1000research.19610.1 
Throughout history, humankind has been preoccupied with longevity, death, and immortality, as evidenced by the first known epic, describing Gilgamesh's futile quest for immortality. Death due to old age, however, appears to be rather rare in nature, as most species are confronted with various extrinsic sources of mortality, including predation, malnutrition, and life-threatening temperatures, all of which can limit the life span of individuals in their natural habitats. The vastly different life spans among closely related species $^{1,2}$ were selected mainly via pressure exerted by extrinsic mortality risks that had to be balanced with the need for successful offspring generation. Some trees may persist thousands of years, whereas some insect species live for only a few days and other species, such as the small freshwater animal hydra, are thought to live indefinitely ${ }^{3}$. Various primate species show considerable life span variations, ranging from around 10 to 60 years, even in protected environments. It is vigorously debated whether humans have a fixed maximum life span that plateaus at 115 years ${ }^{4}$ or whether the mortality risk plateaus past 105 years $^{5}$, leaving open the theoretical possibility of immortality-provided there were an infinite number of 105-year-old individuals. In general, not all individuals of a given species reach the same age, even if they live in the same environment. This variation was most impressively demonstrated in a clonal Caenorhabditis elegans population that even under identical environmental conditions showed a stochastic life span distribution ${ }^{6}$. Genome comparisons from species groups with different life spans have revealed evolutionary signatures in genes, some of which have been implicated in pathways associated with longevity regulation ${ }^{7,8}$. Among these are genes involved in DNA repair, splicesosome and RNA processing, cell cycle control and cell division, kynurenine metabolism, autophagy, wound healing, and hemostasis ${ }^{7,8}$. Such studies offer great potential for identifying aging modulators to enhance our understanding of the factors that govern the dynamics of life span determination.

Over the past three decades, environmental and metabolic factors as well as evolutionarily conserved pathways that influence life span have been identified (Figure 1). Examples include several stress factors that, in excess, can negatively affect life span but that, in moderation, can trigger protective responses that lead to life span extension in a process called hormesis?. For example, DNA damage is thought to accumulate in tissues during aging, as extrinsic and intrinsic sources of genotoxic stress lead to a wide array of DNA lesions, including oxidized DNA bases, apurinic sites, and DNA double-strand breaks (reviewed in 10). DNA damage drives the aging process via mechanisms ranging from interference with replication and transcription to the DNA damage response (DDR) that triggers apoptosis and cellular senescence ${ }^{11}$. A range of congenital DNA repair defects lead to progeroid syndromes that are characterized by accelerated segmental aging phenotypes in humans ${ }^{12,13}$. Reactive oxygen species (ROS) have been prime suspects for accelerating the aging process; however, they can also trigger

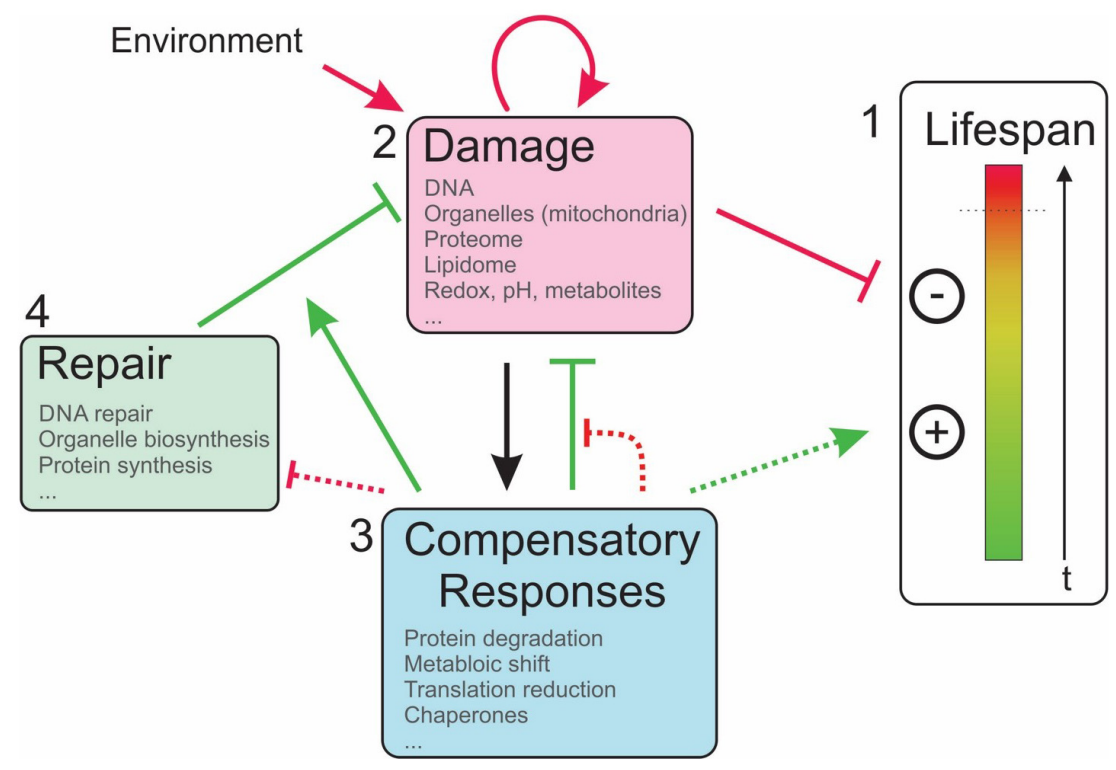

Figure 1. Life span determination. (1) Organismal life starts out as a system in healthy homeostasis (green bar area), which becomes increasingly disorganized via deleterious effects (yellow/red bar area) until it reaches a threshold of system collapse and death (dotted line). Positive and negative effects determine the dynamics of this transition and therefore the life span of the individual. (2) Biological damage leading to disruption of systemic homeostasis can be triggered by environmental insults and internal metabolic processes, which can selfamplify and interact which each other. (3) Damage triggers compensatory responses that limit damage (green blunt arrow), facilitate damage repair (solid green arrow), and delay the complete disruption of homeostasis (dotted green arrow). Over time, compensatory responses exhaust their compensatory capacity and potentially limit repair resources (dotted red arrows). (4) Repair and re-synthesis of biological structures and components at least partially revert some types of damage. Green arrows denote positive effects on life span, red arrows denote negative effects on life span, and black arrows denote neutral or ambiguous effects. 
protective responses at low levels and are even necessary for certain life span extension phenotypes ${ }^{14}$. For example, epigallocatechin-3-gallate (EGCG), a compound found in green tea (Camellia sinensis L.), leads to ROS production and an extended median life span in C. elegans, but this effect is abrogated when the nematodes are treated with the ROS-neutralizing reducing agent $\mathrm{N}$-acetylcysteine (NAC) ${ }^{15}$. Similar positive life span and hormetic effects could be observed with low concentrations of other ROS inducers, such as naphthoquinones and arsenite, in a ROS-dependent manner ${ }^{16,17}$. Moreover, the influence of glycogen and glucose on the intracellular glutathione redox system, concomitant ROS scavenging, and life span reduction in long-lived daf-2 mutant $C$. elegans highlight the importance of ROS signaling and redox systems for life span control $^{18,19}$. Strongly elevated ROS levels, however, induced by higher concentrations of paraquat shorten life span, presum-

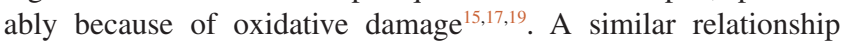
can be observed regarding the nutritional state of animals, as severe nutrient and energy limitation can lead to death; however, calorie restriction (CR), dietary restriction (DR), or intermittent fasting has positive effects on life span in several model organisms, and modulation of metabolic parameters in a 2-year human trial showed potential benefits ${ }^{20-22}$. These life span extensions can also be triggered via modulation of molecular signaling pathways-for example, insulin-like growth factor (IGF) signaling - or via the inhibition of neuronal circuits involved in nutrient sensing ${ }^{23}$. Based on information regarding the signaling mechanisms that mediate the life span-extending consequences of $\mathrm{CR}$, pharmacological inhibitors such as the mammalian target of rapamycin (mTOR) inhibitor rapamycin were shown to be sufficient for life span extension in several model organisms, including mice ${ }^{24}$. Currently, several efforts are underway to develop more specific TORC1 inhibitors to avoid the side effects associated with rapamycin treatment in humans, such as immunosuppression and impaired wound healing ${ }^{25-27}$.

Protein homeostasis, also called proteostasis, describes a compendium of processes that include proteasome-dependent protein degradation, several types of autophagy required for the degradation of biomolecules, protein aggregates and defective organelles (reviewed in 28), as well as downregulation of ribosomal protein translation ${ }^{29,30}$. Enhanced proteostasis mechanisms are often essential components of lifespan-extending pathways (Figure 1). Inhibition of TOR signaling, for instance, reduces the initiation of protein translation, which might then alleviate proteotoxic stress, e.g., the age-related accumulation of protein aggregates $^{30}$. In addition, shifts in overall metabolism might cause or result from changes in proteostatic capacity ${ }^{31}$. For example, mitochondria, which have important roles in energy generation and act as hubs for lipid metabolism and anabolic processes, have been implicated in lifespan regulation. Treatment with the natural compound urolithin A induces mitophagy and extends lifespan in $C$. elegans perhaps by eliminating dysfunctional mitochondria, thus linking autophagy and mitochondrial physiology to life span determination ${ }^{32}$. Their involvement might be context-dependent, as mitochondrial stress responses, such as the mitochondrial unfolded protein response $\left(\mathrm{UPR}^{\mathrm{mt}}\right)$, can contribute to life span extension in C. elegans $^{23}$. In contrast, life span-extending mutations in the electron transport chain complex IV (COX-5B, previously referred to as CCO-1) or cytochrome $c$ reductase (ISP-1) induce $\mathrm{UPR}^{\mathrm{mt}}$ marker expression; however, abrogating this induction via mutation of the transcription factor (TF) ATFS-1 does not ameliorate this life span extension ${ }^{33}$. Zhou et al. demonstrated that the consequence of autophagy can also be context-dependent: whereas increased autophagy is necessary for many life span-extending paradigms (that is, CR), increased mitochondrial permeability can convert elevated autophagy into a life spanshortening process in $C$. elegans ${ }^{34}$. This observation suggests that mitochondrial and autophagic functions may interact to modulate longevity.

A range of TFs and epigenetic and splicing modulators ${ }^{35}$ that regulate stress responses and confer positive effects on life span have been identified. The discovery that attenuation of the insulin-like signaling (IIS) pathway extends life span in C. elegans ignited the field of the genetics of longevity. Importantly, IIS regulates life span via activation of the FOXO TF DAF-16. Since these seminal discoveries, numerous additional life span-regulating TFs have been identified. The HLH-30/ TFEB TF mediates longevity via stress-induced regulation of autophagy-associated genes upon stress. Although these TFs have been characterized in isolation for quite some time, how they can cooperate with a variety of other TFs to regulate life span and stress responses has been recently delineated. Lin et al. suggested that DAF-16/FOXO and HLH-30/TFEB cooperate to regulate longevity and also have important independent functions under specific stress conditions ${ }^{36}$. In contrast, the homeodomain TF CEH-60/PBX, whose role in development has been investigated, was recently shown to negatively affect life span in $C$. elegans by repressing DAF-16 activity ${ }^{37}$. HLH-30 activity, which has positive effects on life span, can be enhanced via treatment with nuclear export blocker drugs $^{38}$ and modulators of intracellular calcium storage compartments $^{39}$. On the level of mRNA processing, the splicing factor SFA-1/SF1 has emerged as a requirement for the proper splicing of transcripts involved in lipid metabolism and other metabolic processes under conditions of life spanextending $\mathrm{DR}^{35}$.

Epigenetic mechanisms are crucial for cell identity and function of differentiated cells, the differentiation of stem cells, and stem cell maintenance. So far, different adult stem cell systems have been identified which show aging-associated changes in epigenetic marks on chromatin and DNA (for example, in hematopoietic stem cells [HSCs], intestinal stem cells, and muscle stem cells [MuSCs]). Cell-intrinsic damage, accumulating during stem cell quiescence, may lead to epigenetic changes, while cell elimination is prevented through anti-apoptotic pathways (reviewed in 40). For example, these changes can lead to divergent deposition of H3K4me3 marks or action of Rad21/ cohesin, resulting in impaired stem cell function and senescence signaling in aged $\mathrm{MuSCs}^{41}$ or over-activation of inflammatory signaling in $\mathrm{HSCs}^{42}$, respectively. Deficiencies in stem cell function, in turn, impair tissue homeostasis, function, and 
regeneration, leading to declining organismal health and most likely limiting life span. Moreover, epigenetic changes in aged stem cells might lead to increased incidences of aging-related diseases such as hematopoietic cancers by allowing the clonal selection of mutated $\mathrm{HSCs}^{43-45}$. Interestingly, transient epigenetic reprogramming via cyclic expression of the Yamanaka factors in mice showed signatures of improved health in a progeroid laminopathy mouse model ${ }^{46}$.

It is becoming increasingly clear that in addition to cellautonomous stress responses that modulate the intrinsic resilience of individual cells upon exposure to specific types of stress, signaling between cells and tissues can elicit such responses both locally and in distal tissues. The influence of these intertissue effects has been exemplified by heterochronic parabiosis and transplantation experiments, which suggest differences in circulating and local niche factors to dynamically alter tissue functionality and epigenetic states during aging ${ }^{40,47,48}$. In particular, neuronal tissue has come into focus as a significant coordinator of life span-modulating processes; for example, neuronal autophagy (as well as autophagy in the intestine) can regulate life span-extending processes non-cell-autonomously ${ }^{49}$. The immune system is an important non-cell-autonomous regulator that not only profoundly influences life span directly by preventing premature death due to infections but also protects organisms via cancer surveillance and removal of senescent cells. While the prowess of the immune system fades during aging through a process called immunosenescence ${ }^{50}$, nuclear DNA damage, accumulating extranuclear DNA, and senescent cells fuel inflammation ${ }^{51}$. Parts of the adaptive immune repertoire of individual aging humans have recently been characterized, and declines in the diversity of $\mathrm{CD}^{+}$ (cytotoxic) T-cell and B-cell repertoires were observed ${ }^{52,53}$. Senescent cells, which adopt a distinct physiology (often via continuous DNA damage signaling ${ }^{11}$ ), have themselves been implicated in impairing normal tissue function and promoting the development of a deleterious, chronic pro-inflammatory environment ${ }^{54-56}$. Targeting senescent cells has shown positive effects on immune function in mice and therefore appears to be a promising field of research to improve tissue aging in the elderly ${ }^{57}$, including attempts to re-establish a balanced output of aging HSCs to regenerate lymphopoiesis during aging ${ }^{58}$. In contrast, the senescence program might protect cells from transforming into cancer cells and has been implicated in tissue regeneration after skin injury ${ }^{59}$. Together, these observations indicate that senescent cells serve dual roles in influencing life span: pro-longevity tumor suppression and tissue repair versus involvement in pro-aging inflammatory reactions.

As the important roles for the immune system and metabolism in life span modulation have been intensely studied for some time, the involvement of the microbiome has emerged more recently. Different microbiota compositions have been shown to modulate both the immune system and metabolism in positive and pathogenic ways. Studies on centenarians have suggested specific signatures in the gut microbiome in terms of its composition and diversity in long-lived humans ${ }^{60,61}$. For example, higher relative abundances of Akkermansia and Bifidobacterium, known health-associated microbes, are positively associated with exceptionally long-lived humans ${ }^{60}$. Furthermore, microbial transfer experiments from young to middle-aged killifish, a short-lived model organism recently established for conducting research on vertebrate aging, demonstrated a positive effect of a young microbiome on life $\operatorname{span}^{62}$.

Many stress factors that influence life span (for example, ROS, mitochondrial impairment, cellular redox imbalance, nutritional status, and protein translation) are intimately connected (Figure 1). Thus, the delineation of clear cause-and-effect relationships between such factors and longevity is challenging. ROS, for example, can cause proteome stress $^{63}$ and lead to DNA damage ${ }^{64}$ among other effects; however, it also stimulates protective (hormetic) responses ${ }^{9}$. DNA damage, in turn, can lead to more ROS production ${ }^{65}$, potentially also via consequential imbalances in the mitochondrial proteome. The DDR, which comprises checkpoint signaling and DNA repair pathways, protects cells from malignant transformation ${ }^{66}$. The DDR can also lead to decreased general translation ${ }^{67}$, which might alleviate proteostatic stress. The involvement of proteostasis in the DDR appears manifold, ranging from distinct roles during DNA repair to ensuring cellular homeostasis. DNA damage remains a central node in the network of these processes, as both exogenous and endogenous genotoxins constantly inflict DNA damage and because the DDR affects a vast range of metabolic and proteostatic responses ${ }^{68}$. Interestingly, CR was shown to dramatically extend life span in nucleotide excision repair-deficient progeroid animals ${ }^{69}$, suggesting a new perspective in the ongoing quest for therapies for congenital progeroid syndromes. Indeed, DAF-16-mediated stress responses to DNA damage in $C$. elegans can preserve tissue maintenance and function by elevating the tolerance to persistent DNA damage ${ }^{70}$.

Interventional studies with the mTOR inhibitor rapamycin have had positive effects on delaying the onset of age-associated chronic disease markers and potentially negative effects in humans ${ }^{71-73}$. In addition to rapamycin, the drugs resveratrol and metformin have been used to modulate pathways involved in DR-mediated life span extension, and senolytic drugs (for example, dasatinib, quercetin ${ }^{74}$, and fisetin $^{75}$ ) have been reported to differentially enhance apoptosis in senescent cells, depending on their original cell type. (Senolytics are reviewed in 76.) Dasatininb and quercetin were recently tested in a first human pilot study on idiopathic pulmonary fibrosis; however, the long-term effects of these treatments have not been assessed ${ }^{77}$. These interventions might indeed provide potential therapeutic options for delaying the aging process; however, drugs for specifically enhancing DNA repair or alleviating DNA damage have not been developed yet. In contrast, the deletion of DDR components was shown to exert positive effects on tissue maintenance and life span in mice that prematurely aged because of telomere dysfunction ${ }^{78-80}$. These results suggest that modulating the DDR could provide interesting avenues for interventions for maintaining tissue homeostasis during aging.

In summary, recent progress has significantly expanded our knowledge of the various processes that modulate life span, including genetic regulators, stress responses, metabolism, 
cellular senescence, and inter-tissue communication. Stochastic effects, such as the occurrence of DNA damage, which can impact each one of those processes ${ }^{68}$ could result in different individual aging trajectories, where hypothetical tipping points of declining tissue functionality are reached at different time points ${ }^{81,82}$. This might be one reason for the heterogeneity of individual life spans even in defined, homogenous model organism populations. Importantly, the interactions between longevity modulators are becoming increasingly apparent, highlighting the complexities underlying aging and life span determination. As multiple factors contribute to aging and the alleviation of age-related organismal deterioration, it might be necessary for future interventions to collectively target a range of longevity modulators-potentially even in a tissue- or cell type-specific manner-to extend the healthy life span in humans.

\section{Grant information}

BS acknowledges funding from the Deutsche Forschungsgemeinschaft (SCHU 2494/3-1, SCHU 2494/7-1, CECAD, SFB 829, SFB 670, KFO 286, KFO 329, and GRK2407), the Deutsche Krebshilfe (70112899), and the European Cooperation in Science and Technology (COST) action (BM1408).

The funders had no role in study design, data collection and analysis, decision to publish, or preparation of the manuscript.
1. $\mathrm{F}$ Jones OR, Scheuerlein A, Salguero-Gómez $\mathrm{R}$, et al:: Diversity of ageing across the tree of life. Nature. 2014; 505(7482): 169-73. PubMed Abstract | Publisher Full Text | Free Full Text | F1000 Recommendation

2. de Magalhães JP, Costa J: A database of vertebrate longevity records and their relation to other life-history traits. J Evol Biol. 2009; 22(8): 1770-4. PubMed Abstract | Publisher Full Text

3. Nilsson Sköld H, Obst M: Potential for clonal animals in longevity and ageing studies. Biogerontology. 2011; 12(5): 387-96. PubMed Abstract | Publisher Full Text

4. $\quad F$ Dong X, Milholland B, Vijg J: Evidence for a limit to human lifespan. Nature. 2016; 538(7624): 257-9.

PubMed Abstract | Publisher Full Text | F1000 Recommendation

5. $\quad F$ Barbi E, Lagona F, Marsili M, et al.: The plateau of human mortality: Demography of longevity pioneers. Science. 2018; 360(6396): 1459-61. PubMed Abstract | Publisher Full Text | Free Full Text | F1000 Recommendation

6. $\quad F$ Herndon LA, Schmeissner PJ, Dudaronek JM, et al:: Stochastic and genetic factors influence tissue-specific decline in ageing C. elegans. Nature. 2002; 419(6909): 808-14.

PubMed Abstract | Publisher Full Text | F1000 Recommendation

7. F Muntané G, Farré X, Rodríguez JA, et al:: Biological Processes Modulating Longevity across Primates: A Phylogenetic Genome-Phenome Analysis. Mol Biol Evol. 2018; 35(8): 1990-2004.

PubMed Abstract | Publisher Full Text | Free Full Text | F1000 Recommendation

8. F Wirthlin M, Lima NCB, Guedes RLM, et al:: Parrot Genomes and the Evolution of Heightened Longevity and Cognition. Curr Biol. 2018; 28(24) 4001-4008.e7.

PubMed Abstract | Publisher Full Text | Free Full Text | F1000 Recommendation

9. Schumacher B: Transcription-blocking DNA damage in aging: a mechanism for hormesis. BioEssays. 2009; 31(12): 1347-56.

PubMed Abstract | Publisher Full Text

10. Moskalev AA, Shaposhnikov MV, Plyusnina EN, et al:: The role of DNA damage and repair in aging through the prism of Koch-like criteria. Ageing Res Rev. 2013; 12(2): 661-84.

PubMed Abstract | Publisher Full Text

11. Fumagalli M, Rossiello F, Mondello $C$, et al:: Stable Cellular Senescence Is Associated with Persistent DDR Activation. PLOS One. 2014; 9(10): e110969. PubMed Abstract | Publisher Full Text | Free Full Text

12. Hoeijmakers JH: DNA damage, aging, and cancer. N Engl J Med. 2009; 361(15): 1475-85.

PubMed Abstract | Publisher Full Text

13. Madabhushi R, Pan L, Tsai LH: DNA damage and its links to neurodegeneration. Neuron. 2014; 83(2): 266-82.

PubMed Abstract | Publisher Full Text | Free Full Text

14. F Scialò F, Sriram A, Fernández-Ayala D, et al:: Mitochondrial Ros Produced via Reverse Electron Transport Extend Animal Lifespan. Cell Metab. 2016; 23(4): 725-34.

PubMed Abstract | Publisher Full Text | Free Full Text | F1000 Recommendation

15. F Xiong LG, Chen YJ, Tong JW, et al:: Epigallocatechin-3-gallate promotes healthy lifespan through mitohormesis during early-to-mid adulthood in
Caenorhabditis elegans. Redox Biol. 2018; 14: 305-15

PubMed Abstract | Publisher Full Text | Free Full Text | F1000 Recommendation

16. Schmeisser S, Schmeisser K, Weimer S, et al:: Mitochondrial hormesis links lowdose arsenite exposure to lifespan extension. Aging Cell. 2013; 12(3): 508-17. PubMed Abstract | Publisher Full Text | Free Full Text

17. Hunt PR, Son TG, Wilson MA, et al:: Extension of lifespan in C. elegans by naphthoquinones that act through stress hormesis mechanisms. PLoS One. 2011; 6(7): e21922.

PubMed Abstract | Publisher Full Text | Free Full Text

18. Gusarov I, Nudler E: Glycogen at the Crossroad of Stress Resistance, Energy Maintenance, and Pathophysiology of Aging. BioEssays. 2018; 40(9): e1800033. PubMed Abstract | Publisher Full Text

19. Gusarov I, Pani B, Gautier L, et al.: Glycogen controls Caenorhabditis elegans lifespan and resistance to oxidative stress. Nat Commun. 2017; 8: 15868. PubMed Abstract | Publisher Full Text | Free Full Text

20. Singh PP, Demmitt BA, Nath RD, et al.: The Genetics of Aging: A Vertebrate Perspective. Cell. 2019; 177(1): 200-20. PubMed Abstract | Publisher Full Text

21. F Redman LM, Smith SR, Burton JH, et al:: Metabolic Slowing and Reduced Oxidative Damage with Sustained Caloric Restriction Support the Rate of Living and Oxidative Damage Theories of Aging. Cell Metab. 2018; 27(4): 805-815.e4.

PubMed Abstract | Publisher Full Text | Free Full Text | F1000 Recommendation

22. Mattison JA, Colman RJ, Beasley TM, et al.: Caloric restriction improves health and survival of rhesus monkeys. Nat Commun. 2017; 8: 14063. PubMed Abstract | Publisher Full Text | Free Full Text

23. Denzel MS, Lapierre LR, Mack HID: Emerging topics in C. elegans aging research: Transcriptional regulation, stress response and epigenetics. Mech Ageing Dev. 2019; 177: 4-21.

PubMed Abstract | Publisher Full Text

24. F Harrison DE, Strong R, Sharp ZD, et al.: Rapamycin fed late in life extends lifespan in genetically heterogeneous mice. Nature. 2009; 460(7253): 392-5. PubMed Abstract | Publisher Full Text | Free Full Text | F1000 Recommendation

25. Cravedi $P$, Ruggenenti $P$, Remuzzi G: Sirolimus for calcineurin inhibitors in organ transplantation: contra. Kidney Int. 2010; 78(11): 1068-74. PubMed Abstract | Publisher Full Text

26. Benjamin D, Colombi M, Moroni C, et al:: Rapamycin passes the torch: a new generation of mTOR inhibitors. Nat Rev Drug Discov. 2011; 10(11): 868-80. PubMed Abstract | Publisher Full Text

27. Tang D, Tao S, Chen Z, et al: Dietary restriction improves repopulation but impairs lymphoid differentiation capacity of hematopoietic stem cells in early aging. J Exp Med. 2016; 213(4): 535-53.

PubMed Abstract | Publisher Full Text | Free Full Text

28. Hansen M, Rubinsztein DC, Walker DW: Autophagy as a promoter of longevity: insights from model organisms. Nat Rev Mol Cell Biol. 2018; 19(9): 579-93. PubMed Abstract | Publisher Full Text | Free Full Text

29. $\mathrm{F}$ Molenaars M, Janssens GE, Santermans $\mathrm{T}$, et al.: Mitochondrial ubiquinonemediated longevity is marked by reduced cytoplasmic mRNA translation. Life Sci Alliance. 2018; 1(5)

PubMed Abstract | Publisher Full Text | Free Full Text | F1000 Recommendation

30. F Solis GM, Kardakaris R, Valentine ER, et al:: Translation attenuation 
by minocycline enhances longevity and proteostasis in old post-stressresponsive organisms. eLife. 2018; 7: pii: e40314.

PubMed Abstract | Publisher Full Text | Free Full Text | F1000 Recommendation

31. López-Otín C, Galluzzi L, Freije JMP, et al:: Metabolic Control of Longevity. Cell. 2016; 166(4): 802-21.

PubMed Abstract | Publisher Full Text

32. F Ryu D, Mouchiroud L, Andreux PA, et al:: Urolithin A induces mitophagy and prolongs lifespan in $C$. elegans and increases muscle function in rodents. Nat Med. 2016; 22(8): 879-88.

PubMed Abstract | Publisher Full Text | F1000 Recommendation

33. Bennett CF, Vander Wende H, Simko M, et al.: Activation of the mitochondrial unfolded protein response does not predict longevity in Caenorhabditis elegans. Nat Commun. 2014; 5: 3483.

PubMed Abstract | Publisher Full Text | Free Full Text

34. F Zhou B, Kreuzer J, Kumsta C, et al.: Mitochondrial Permeability Uncouples Elevated Autophagy and Lifespan Extension. Cell. 2019; 177(2): 299-314.e16. PubMed Abstract | Publisher Full Text | Free Full Text | F1000 Recommendation

35. F Heintz C, Doktor TK, Lanjuin A, et al:: Splicing factor 1 modulates dietary restriction and TORC1 pathway longevity in C. elegans. Nature. 2017; 541(7635): 102-6.

PubMed Abstract | Publisher Full Text | Free Full Text | F1000 Recommendation

36. F Lin XX, Sen I, Janssens GE, et al.: DAF-16/FOXO and HLH-30/TFEB function as combinatorial transcription factors to promote stress resistance and longevity. Nat Commun. 2018; 9(1): 4400.

PubMed Abstract | Publisher Full Text | Free Full Text | F1000 Recommendation

37. F Dowen RH: CEH-60/PBX and UNC-62/MEIS Coordinate a Metabolic Switch that Supports Reproduction in C. elegans. Dev Cell. 2019; 49(2): 235-250.e7. PubMed Abstract | Publisher Full Text | F1000 Recommendation

38. F Silvestrini MJ, Johnson JR, Kumar AV, et al:: Nuclear Export Inhibition Enhances HLH-30/TFEB Activity, Autophagy, and Lifespan. Cell Rep. 2018; 23(7): 1915-21.

PubMed Abstract | Publisher Full Text | Free Full Text | F1000 Recommendation

39. Wang C, Niederstrasser H, Douglas PM, et al.: Small-molecule TFEB pathway agonists that ameliorate metabolic syndrome in mice and extend $C$. elegans lifespan. Nat Commun. 2017; 8(1): 2270.

PubMed Abstract | Publisher Full Text | Free Full Text

40. Ermolaeva M, Neri F, Ori A, et al:: Cellular and epigenetic drivers of stem cell ageing. Nat Rev Mol Cell Biol. 2018; 19(9): 594-610.

PubMed Abstract | Publisher Full Text

41. F Schwörer S, Becker F, Feller C, et al.: Epigenetic stress responses induce muscle stem-cell ageing by Hoxa9 developmental signals. Nature. 2016; 540(7633): 428-32

PubMed Abstract | Publisher Full Text | Free Full Text | F1000 Recommendation

42. F Chen Z, Amro EM, Becker F, et al:: Cohesin-mediated NF- B signaling limits hematopoietic stem cell self-renewal in aging and inflammation. J Exp Med. 2019; 216(1): 152-75

PubMed Abstract | Publisher Full Text | Free Full Text | F1000 Recommendation

43. F Busque L, Patel JP, Figueroa ME, et al:: Recurrent somatic TET2 mutations in normal elderly individuals with clonal hematopoiesis. Nat Genet. 2012; 44(11): 1179-81.

PubMed Abstract | Publisher Full Text | Free Full Text | F1000 Recommendation

44. F Jaiswal S, Fontanillas P, Flannick J, et al.: Age-related clonal hematopoiesis associated with adverse outcomes. N Engl J Med. 2014; 371(26): 2488-98. PubMed Abstract | Publisher Full Text | Free Full Text | F1000 Recommendation

45. F Jaiswal S, Natarajan P, Silver AJ, et al: Clonal Hematopoiesis and Risk of Atherosclerotic Cardiovascular Disease. N Engl J Med. 2017; 377(2): 111-21. PubMed Abstract | Publisher Full Text | F1000 Recommendation

46. F Ocampo A, Reddy P, Martinez-Redondo P, et al:: In Vivo Amelioration of Age-Associated Hallmarks by Partial Reprogramming. Cell. 2016; 167(7): 1719-1733.e12.

PubMed Abstract | Publisher Full Text | Free Full Text | F1000 Recommendation

47. F Villeda SA, Luo J, Mosher KI, et al.: The ageing systemic milieu negatively regulates neurogenesis and cognitive function. Nature. 2011 ; 477(7362): 90-4. PubMed Abstract | Publisher Full Text | Free Full Text | F1000 Recommendation

48. F Conboy IM, Conboy MJ, Wagers AJ, et al.: Rejuvenation of aged progenitor cells by exposure to a young systemic environment. Nature. 2005; 433(7027): 760-4.

PubMed Abstract | Publisher Full Text | F1000 Recommendation

49. Minnerly J, Zhang J, Parker T, et al:: The cell non-autonomous function of ATG-18 is essential for neuroendocrine regulation of Caenorhabditis elegans lifespan. PLoS Genet. 2017; 13(5): e1006764. PubMed Abstract | Publisher Full Text | Free Full Text

50. Montecino-Rodriguez E, Berent-Maoz B, Dorshkind K: Causes, consequences, and reversal of immune system aging. J Clin Invest. 2013; 123(3): 958-65. PubMed Abstract | Publisher Full Text | Free Full Text

51. $\mathrm{F}$ Lan $\mathrm{YY}$, Heather JM, Eisenhaure T, et al:: Extranuclear DNA accumulates in aged cells and contributes to senescence and inflammation. Aging Cell. 2019;
18(2): e12901.

PubMed Abstract | Publisher Full Text | Free Full Text | F1000 Recommendation

52. Yoshida $\mathrm{K}$, Cologne JB, Cordova $\mathrm{K}$, et al: Aging-related changes in human T-cell repertoire over 20years delineated by deep sequencing of peripheral T-cell receptors. Exp Gerontol. 2017; 96: 29-37.

PubMed Abstract | Publisher Full Text

53. $\mathrm{F}$ de Bourcy CF, Angel CJ, Vollmers C, et al:: Phylogenetic analysis of the human antibody repertoire reveals quantitative signatures of immune senescence and aging. Proc Natl Acad Sci U S A. 2017; 114(5): 1105-10. PubMed Abstract | Publisher Full Text | Free Full Text | F1000 Recommendation

54. Xu M, Tchkonia T, Ding $\mathrm{H}$, et al:: JAK inhibition alleviates the cellular senescence-associated secretory phenotype and frailty in old age. Proc Natl Acad Sci U S A. 2015; 112(46): E6301-E6310.

PubMed Abstract | Publisher Full Text | Free Full Text

55. Bektas A, Schurman SH, Sen R, et al.: Aging, inflammation and the environment. Exp Gerontol. 2018; 105: 10-8.

PubMed Abstract | Publisher Full Text | Free Full Text

56. Bektas A, Schurman SH, Sen R, et al:: Human T cell immunosenescence and inflammation in aging. $J$ Leukoc Biol. 2017; 102(4): 977-88. PubMed Abstract | Publisher Full Text | Free Full Text

57. F Palacio L, Goyer ML, Maggiorani D, et al.: Restored immune cell functions upon clearance of senescence in the irradiated splenic environment. Aging Cell. 2019; 18(4): e12971.

PubMed Abstract | Publisher Full Text | Free Full Text | F1000 Recommendation

58. F Wang J, Morita Y, Han B, et al:: Per2 induction limits lymphoid-biased haematopoietic stem cells and lymphopoiesis in the context of DNA damage and ageing. Nat Cell Biol. 2016; 18(5): 480-90.

PubMed Abstract | Publisher Full Text | F1000 Recommendation

59. Demaria M, Ohtani N, Youssef SA, et al:: An essential role for senescent cells in optimal wound healing through secretion of PDGF-AA. Dev Cell. 2014; 31(6): 722-33.

PubMed Abstract | Publisher Full Text | Free Full Text

60. F Biagi E, Franceschi C, Rampelli S, et al:: Gut Microbiota and Extreme Longevity. Curr Biol. 2016; 26(11): 1480-5.

PubMed Abstract | Publisher Full Text | F1000 Recommendation

61. F Tuikhar N, Keisam S, Labala RK, et al:: Comparative analysis of the gut microbiota in centenarians and young adults shows a common signature across genotypically non-related populations. Mech Ageing Dev. 2019; 179: 23-35.

PubMed Abstract | Publisher Full Text | F1000 Recommendation

62. F Smith $\mathrm{P}$, Willemsen D, Popkes M, et al.: Regulation of life span by the gut microbiota in the short-lived African turquoise killifish. eLife. 2017; 6: pii: e27014.

PubMed Abstract | Publisher Full Text | Free Full Text | F1000 Recommendation

63. Berlett BS, Stadtman ER: Protein oxidation in aging and disease. Free Radic Biol Med. 2003; 27: S4.

64. Cadet J, Wagner JR: DNA base damage by reactive oxygen species, oxidizing agents, and UV radiation. Cold Spring Harb Perspect Biol. 2013; 5(2): pii: a012559.

PubMed Abstract | Publisher Full Text | Free Full Text

65. F Gurkar AU, Robinson AR, Cui Y, et al.: Dysregulation of DAF-16/FOXO3Amediated stress responses accelerates oxidative DNA damage induced aging. Redox Biol. 2018; 18: 191-9.

PubMed Abstract | Publisher Full Text | Free Full Text | F1000 Recommendation

66. Blackford AN, Jackson SP: ATM, ATR, and DNA-PK: The Trinity at the Heart of the DNA Damage Response. Mol Cell. 2017; 66(6): 801-17. PubMed Abstract | Publisher Full Text

67. Loveless TB, Topacio BR, Vashisht AA, et al:: DNA Damage Regulates Translation through $\boldsymbol{\beta}$-TRCP Targeting of CReP. PLoS Genet. 2015; 11(6): e1005292.

PubMed Abstract | Publisher Full Text | Free Full Text

68. $\mathrm{F}$ Edifizi D, Nolte $\mathrm{H}, \mathrm{Babu} \mathrm{V}$, et al:: Multilayered Reprogramming in Response to Persistent DNA Damage in C. elegans. Cell Rep. 2017; 20(9): 2026-43. PubMed Abstract | Publisher Full Text | Free Full Text | F1000 Recommendation

69. F Vermeij WP, Dollé ME, Reiling E, et al:: Restricted diet delays accelerated ageing and genomic stress in DNA-repair-deficient mice. Nature. 2016; 537(7620): 427-31.

PubMed Abstract | Publisher Full Text | Free Full Text | F1000 Recommendation

70. Mueller MM, Castells-Roca L, Babu V, et al:: DAF-16/FOXO and EGL-27/GATA promote developmental growth in response to persistent somatic DNA damage. Nat Cell Biol. 2014; 16(12): 1168-79.

PubMed Abstract | Publisher Full Text | Free Full Text

71. Urfer SR, Kaeberlein TL, Mailheau S, et al.: A randomized controlled trial to establish effects of short-term rapamycin treatment in 24 middle-aged companion dogs. Geroscience. 2017; 39(2): 117-27. PubMed Abstract | Publisher Full Text | Free Full Text

72. Mannick JB, Del Giudice G, Lattanzi M, et al.: mTOR inhibition improves immune function in the elderly. Sci Transl Med. 2014; 6(268): 268ra179.

PubMed Abstract | Publisher Full Tex 
73. F Mannick J: TORC1 INHIBITION AS A POTENTIAL IMMUNOTHERAPY TO REDUCE INFECTIONS IN THE ELDERLY. Innov Aging. 2018; 2(Suppl 1): 545. Publisher Full Text | Free Full Text | F1000 Recommendation

74. F Xu M, Pirtskhalava T, Farr JN, et al.: Senolytics improve physical function and increase lifespan in old age. Nat Med. 2018; 24(8): 1246-56. PubMed Abstract | Publisher Full Text | Free Full Text | F1000 Recommendation

75. F Yousefzadeh MJ, Zhu Y, McGowan SJ, et al.: Fisetin is a senotherapeutic that extends health and lifespan. EBioMedicine. 2018; 36: 18-28. PubMed Abstract | Publisher Full Text | Free Full Text | F1000 Recommendation

76. F Kirkland JL, Tchkonia T, Zhu Y, et al:: The Clinical Potential of Senolytic Drugs. J Am Geriatr Soc. 2017; 65(10): 2297-301. PubMed Abstract | Publisher Full Text | Free Full Text | F1000 Recommendation

77. F Justice JN, Nambiar AM, Tchkonia T, et al:: Senolytics in idiopathic pulmonary fibrosis: Results from a first-in-human, open-label, pilot study. EBioMedicine. 2019; 40: 554-63.

PubMed Abstract | Publisher Full Text | Free Full Text | F1000 Recommendation

78. F Choudhury AR, Ju Z, Djojosubroto MW, et al:: Cdkn1a deletion improves stem cell function and lifespan of mice with dysfunctional telomeres without accelerating cancer formation. Nat Genet. 2007; 39(1): 99-105. PubMed Abstract | Publisher Full Text | F1000 Recommendation

79. Schaetzlein S, Kodandaramireddy NR, Ju Z, et al:: Exonuclease-1 deletion impairs DNA damage signaling and prolongs lifespan of telomeredysfunctional mice. Cell. 2007; 130(5): 863-77. PubMed Abstract | Publisher Full Text | Free Full Text

80. Sperka $\mathrm{T}$, Song $\mathrm{Z}$, Morita $\mathrm{Y}$, et al.: Puma and $\mathrm{p} 21$ represent cooperating checkpoints limiting self-renewal and chromosomal instability of somatic stem cells in response to telomere dysfunction. Nat Cell Biol. 2012; 14(1): 73-9.

PubMed Abstract | Publisher Full Text

81. F Sarnoski EA, Song R, Ertekin E, et al:: Fundamental Characteristics of Single-Cell Aging in Diploid Yeast. iScience. 2018; 7: 96-109. PubMed Abstract | Publisher Full Text | Free Full Text | F1000 Recommendation

82. F Song R, Sarnoski EA, Acar M: The Systems Biology of Single-Cell Aging. iScience. 2018; 7: 154-69.

PubMed Abstract | Publisher Full Text | Free Full Text | F1000 Recommendation 


\section{Open Peer Review}

\section{Current Peer Review Status:}

\section{Editorial Note on the Review Process}

Faculty Reviews are review articles written by the prestigious Members of Faculty Opinions. The articles are commissioned and peer reviewed before publication to ensure that the final, published version is comprehensive and accessible. The reviewers who approved the final version are listed with their names and affiliations.

\section{The reviewers who approved this article are:}

\section{Version 1}

\section{K Lenhard Rudolph}

Research Group on Stem Cell Aging, Leibniz Institute on Aging, Fritz Lipmann Institute (FLI), Jena, Germany

Competing Interests: No competing interests were disclosed.

\section{Jan Vijg} Department of Genetics, Albert Einstein College of Medicine, New York, USA

Competing Interests: JV is the founder of the biotech company Singulomics.

\section{Evgeny Nudler}

Department of Biochemistry and Molecular Pharmacology, New York University School of Medicine, New York, USA

Competing Interests: No competing interests were disclosed.

The benefits of publishing with F1000Research:

- Your article is published within days, with no editorial bias

- You can publish traditional articles, null/negative results, case reports, data notes and more

- The peer review process is transparent and collaborative

- Your article is indexed in PubMed after passing peer review

- Dedicated customer support at every stage

For pre-submission enquiries, contact research@f1000.com 